\title{
Transmission Electron Microscope Investigation of the Interface between Titanium and Zirconia
}

\author{
Kun-Fung Lin and Chien-Cheng Lin ${ }^{*}$ \\ Department of Materials Science and Engineering, National Chiao Tung University, Hsinchu, Taiwan 300
}

\begin{abstract}
The interfaces between 3-mol\%-yttria-partially-stabilized zirconia and commercially pure titanium after reaction at $1750^{\circ} \mathrm{C}$ were analyzed with a scanning electron microscope and an analytical transmission microscope. Zirconia was reduced to oxygen-deficient zirconia $\left(\mathrm{ZrO}_{2-x}\right)$ with an $\mathrm{O} / \mathrm{Zr}$ ratio as low as 1.53, causing the evolution of oxygen. Part of the oxygen could accumulate at grain boundaries, the remainder being dissolved in titanium as $\alpha-\operatorname{Ti}(O)$. An ordered titanium suboxide $\left(\mathrm{Ti}_{3} \mathrm{O}\right)$ could be formed from a solid solution of $\alpha-\mathrm{Ti}(\mathrm{O})$ during cooling. A fine crystalline $\mathrm{ZrO}_{2-x}$ phase $(\mathrm{O} / \mathrm{Zr} \approx 2)$ was also found along with $\alpha-\mathrm{Zr}$ near the interface on the zirconia side. The $\alpha-Z r$ was twinned with one of the twin planes being indexed as $\{1012\}$. The yttria stabilizer was excluded from zirconia as the reaction was progressing, existing as oxygen-deficient yttria. Extensive dissolution of zirconia in titanium gave rise to the formation of $\alpha-\mathrm{Ti}(\mathrm{Zr}, \mathrm{O})$ solid solution. On cooling, lamellae of $\mathrm{Ti}_{2} \mathrm{ZrO}$ precipitated from $\alpha$-Ti( $\left.\mathrm{Zr}, \mathrm{O}\right)$ with an orientation relationship of $\{1 \overline{10}\}_{\mathrm{Ti}_{2} \mathrm{ZrO}} / /\{100\}_{\alpha-\mathrm{Ti}}$ and $\langle\mathbf{1 1} \overline{1}\rangle_{\mathrm{Ti}_{2} \mathrm{ZrO}} / /\langle 011\rangle_{\alpha-\mathrm{Ti}^{\circ}}$
\end{abstract}

\section{Introduction}

$\mathrm{T}$ ITANIUM alloys have excellent properties such as high specific strength and good corrosion resistance. However, they are extremely reactive to ceramics at high temperatures, resulting in chemical reactions. ${ }^{1}$ Interstitial elements (e.g., C, N, O, $\mathrm{H})$ from ceramics have a great tendency to enter into titanium alloys during casting and cause the deterioration of mechanical properties, such as ductility, hardness, and toughness. ${ }^{2-6}$

Titanium is often melted in a water-cooled copper crucible by consumable electrode vacuum arc melting instead of vacuum induction melting (VIM) because ceramic crucibles, used in the VIM process, can react with the titanium melt. However, there are many disadvantages with the arc melting process, for example, the high cost of the equipment, difficulty in temperature control, scrape recycle, alloy modification, and long cycle time. Vacuum induction skull melting of titanium castings requires chemical milling of the surfaces in order to remove the reaction products. The VIM process could be profitable in industry if a suitable crucible material were available. Therefore, how to control the interfacial reactions between titanium and ceramics is of great concern.

Extensive investigations have been done on the reactions between $\mathrm{Ti}$ and $\mathrm{ZrO}_{2}$, mostly by using scanning electron microscopy (SEM) and XRD analyses. The formation of oxygendeficient zirconia gives rise to the blackening of zirconia after

R. A. Cutler-contributing editor

Manuscript No. 190229. Received April 27, 1998; approved May 20, 1999 Supported by the National Science Council, Taiwan, under Grant No. NSC872216-E009-014.

Member, American Ceramic Society. reaction. ${ }^{2,7}$ Economos and Kingery ${ }^{8}$ displayed the penetration of titanium along grain boundaries without the formation of any new interfacial phase except the oxygen-deficient zirconia. However, Weber et al. ${ }^{9}$ indicated that limited metals were dissolved in oxides, giving rise to the black color of the oxides. They also reported that a crucible of $\mathrm{ZrO}_{2}$ plus 15 at.\% Ti had the best performance for titanium melting, compared with $\mathrm{TiC}$, $\mathrm{ThO}_{2}, \mathrm{CeS}, \mathrm{TiO}_{1.97}, 15.5 \mathrm{~mol} \% \mathrm{MgO}-\mathrm{ZrO}_{2}$, and pure $\mathrm{ZrO}_{2}$. $\mathrm{Ruh}^{2}$ reported that up to $10 \mathrm{~mol} \%$ of each of $\mathrm{Zr}$ and $\mathrm{O}$ could be retained in a solid solution of $\mathrm{Ti}$ at temperatures ranging from $1200^{\circ}$ to $2000^{\circ} \mathrm{C}$, while the solubility of $\mathrm{Ti}$ in $\mathrm{ZrO}_{2}$ was up to 4 at.\%. Some studies ${ }^{10,11}$ stated that the dissolution of oxygen due to the interfacial reactions could increase the hardness of titanium, while the microhardness profile was primarily an indicator of variation in oxygen concentration. Furthermore, oxygen was preferably transferred from oxides to titanium, leaving behind metallic components as lower oxides in the mold. Lyon ${ }^{12}$ observed that $\mathrm{Y}_{2} \mathrm{O}_{3}$ was reduced to $\mathrm{Y}_{2} \mathrm{O}_{2.94}$ by molten titanium, and a few flowerlike $\mathrm{Y}_{2} \mathrm{O}_{3}$ particles precipitated in the Ti matrix.

In a previous study on the phase transformation of nonstoichiometric zirconia, Ruh and Garrett ${ }^{13}$ stated that a striated intergranular $\alpha-\mathrm{Zr}$ was precipitated during cubic-tetragonal transformation. Upon subsequent annealing below the transformation temperature, this precipitate assumed a low-energy spherical shape. $\mathrm{Ruh}^{2}$ also reported that metallic $\mathrm{ZrTi}(\mathrm{O})$ could form during the interfacial reactions between titanium and zirconia.

Some previous studies discussed the effect of titanium additive on the stabilization and mechanical properties of zirconia. ${ }^{14,15}$ Weber et al. $^{14}$ stated that the addition of titanium (11.9-22.3 at.\%) could improve the strength and thermal shock resistance of zirconia. The improved properties were attributed by Ruh et al. ${ }^{7}$ to better sintering and densification. Lin et al. ${ }^{15}$ reported that the enhancement in mechanical properties was due to the partial stabilization of $\mathrm{ZrO}_{2}$ in the system of (5-50 $\mathrm{mol} \%)^{\mathrm{Ti}} / \mathrm{ZrO}_{2}$ as well as the refinement of grain size. The dissolution of TiO, formed by internal oxidation, could stabilize zirconia, while a second phase in the grain boundaries could cause a decrease in the grain size of $\mathrm{ZrO}_{2}$. At temperatures above $1200^{\circ} \mathrm{C}$ only about 4 at. \% Ti was soluble in $\mathrm{ZrO}_{2}$, even though titanium could dissolve more than $20 \mathrm{wt} \% \mathrm{ZrO}_{2}$ with the formation of a solid solution of $\alpha-\mathrm{Ti}(\mathrm{Zr}, \mathrm{O})$. Since the titanium additive in these studies exceeded the solubility limit of titanium in zirconia, the precipitation of $(\mathrm{Ti}, \mathrm{Zr})_{3} \mathrm{O}$ from the solid solution of $\alpha-\mathrm{Ti}(\mathrm{Zr}, \mathrm{O})$ during cooling could be predicted by a pseudobinary diagram of $\mathrm{Ti}-\mathrm{ZrO}_{2} \cdot{ }^{16}$ However, Weber et al. ${ }^{14}$ and Lin et al. ${ }^{15}$ reported neither $(\mathrm{Ti}, \mathrm{Zr})_{3} \mathrm{O}$ nor $\alpha-\mathrm{Ti}(\mathrm{Zr}, \mathrm{O})$.

The difficulties in preparing cross-sectional specimens have discouraged many investigators from analyzing the microstructures of the interface between zirconia and titanium using transmission electron microscopy. However, the microstructure must be characterized before the reaction mechanisms are explored. In the present study, we will investigate the microstructure of the interface between $\mathrm{Ti}$ and $\mathrm{ZrO}_{2}$ using analytical transmission electron microscopy (TEM) as well as scanning electron microscopy (SEM). 

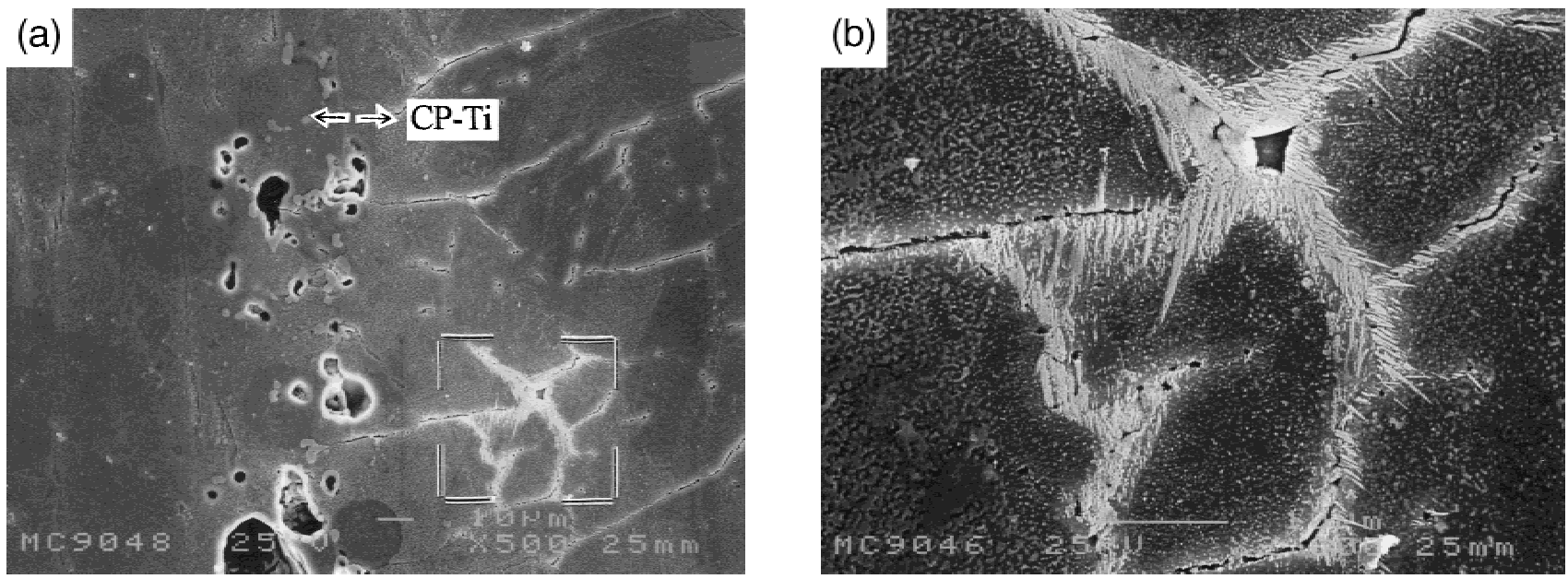

Fig. 1. (a) SEM micrograph of the cross section between titanium and 3-mol\%-yttria-stabilized zirconia after reaction at $1750^{\circ} \mathrm{C}$ for 7 min. (b) A larger magnification of the marked region in (a) showing the featherlike phase at the grain boundaries of titanium.
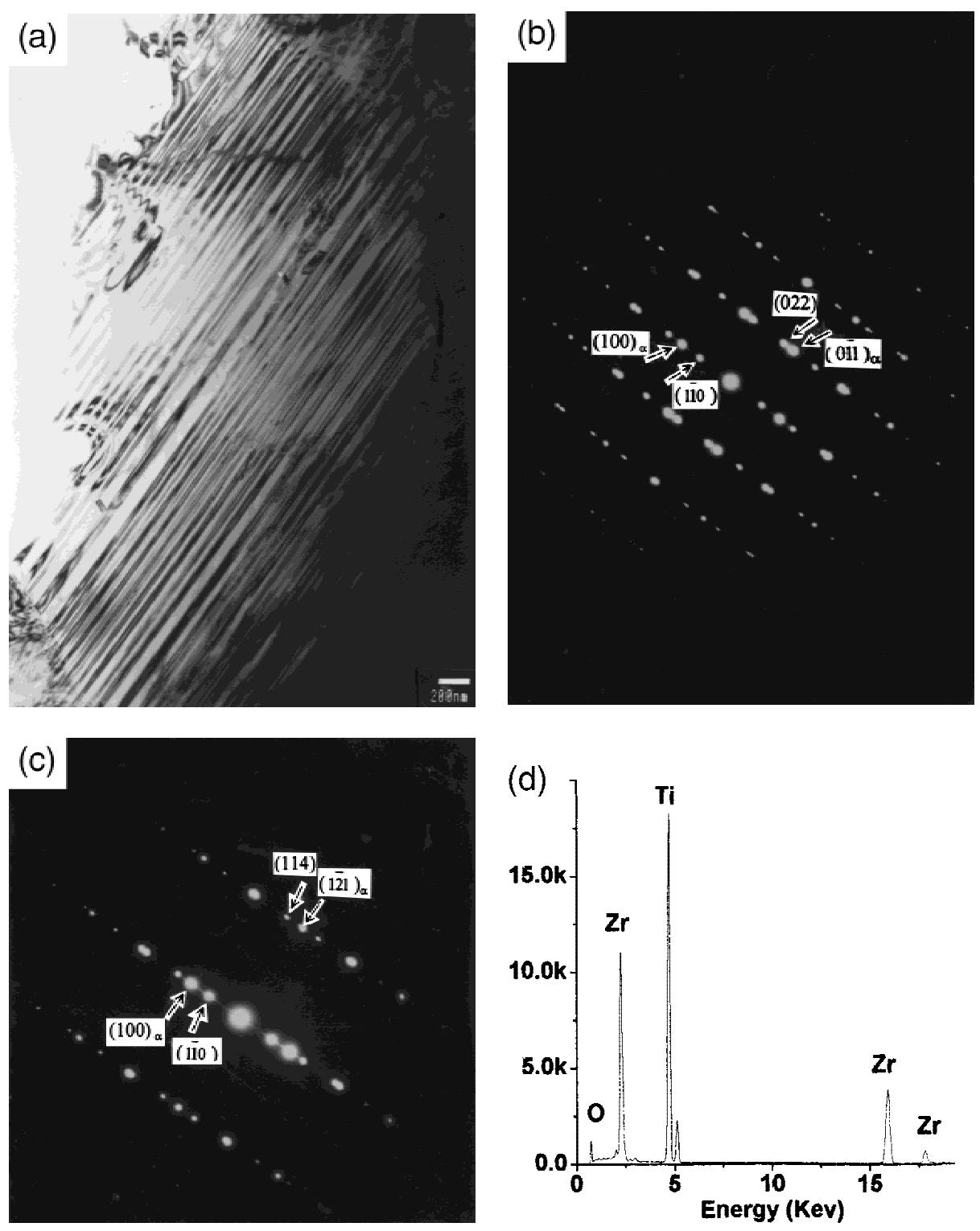

Fig. 2. (a) TEM micrograph showing parallel lamellae $\mathrm{Ti}_{2} \mathrm{ZrO}$ in the matrix of $\alpha$-Ti. (b) SADP in the zone axis of $[11 \overline{1}]_{\mathrm{Ti} 2 \mathrm{ZrO}}$ or $[011]_{\alpha-\mathrm{Ti}}$. (c) $\mathrm{SADP}$ in the zone axis of $[221]_{\mathrm{Ti}_{2} \mathrm{ZrO}}$ or $[012]_{\alpha-\mathrm{Ti}}$. (d) EDS of Ti $\mathrm{ZrO}$. The Miller indices with a subscript $\alpha$ are for $\alpha$-titanium, while those without any subscript are for $\mathrm{Ti}_{2} \mathrm{ZrO}$. 


\section{Experimental Procedure}

Several yttria-partially-stabilized $\mathrm{ZrO}_{2}$ plates were first made by tape casting from a slurry of poly(vinyl alcohol), water, and $3 \mathrm{~mol} \% \mathrm{Y}_{2} \mathrm{O}_{3}-\mathrm{ZrO}_{2}$ powder (1 $\mu \mathrm{m}$ average; First Rare Earth Inc., Japan), and then sintered in air at $1500^{\circ} \mathrm{C} / 2 \mathrm{~h}$. After sintering, a zirconia plate $(\sim 2 \mathrm{~mm}$ thick) was vertically placed into each $5 \mathrm{~mol} \% \mathrm{CaO}-\mathrm{ZrO}_{2}$ crucible (ZR-5, Nikkato Co., Osaka, Japan), and then tightly packed with commercially titanium powder $(-200$ mesh, with impurities of $460 \mathrm{ppm} \mathrm{Zr}$, 350 ppm N, 260 ppm O, <1 ppm Na, <10 ppm Ca; T-2045, Cerac Inc., Milwaukee, WI). The zirconia crucible was then loaded into an argon atmosphere furnace with tungsten mesh heating elements (Model 4156, Centorr Inc., Nashua, NH), whose chamber was evacuated to $10^{-4}$ torr and then refilled with argon to $1 \mathrm{~atm}$. This cycle of evacuation and purging was repeated at least twice. It took $30 \mathrm{~min}$ to raise the temperature from $100^{\circ}$ to $1600^{\circ} \mathrm{C}$ and $5 \mathrm{~min}$ from $1600^{\circ}$ to $1750^{\circ} \mathrm{C}$, and then it was held at $1750^{\circ} \mathrm{C}$ for $7 \mathrm{~min}$. The zirconia plate became immersed in the titanium melt above the melting temperature of titanium $\left(1670^{\circ} \mathrm{C}\right)$, causing an extensive interfacial reaction between the $\mathrm{ZrO}_{2}$ plate and the titanium melt. During cooling, the temperature was lowered to $1600^{\circ} \mathrm{C}$ at a cooling rate of $30^{\circ} \mathrm{C} / \mathrm{min}$ in the furnace, to $1000^{\circ} \mathrm{C}$ at $50^{\circ} \mathrm{C} /$ min. The specimen was then continuously cooled down to room temperature at $10^{\circ} \mathrm{C} / \mathrm{min}$. The interface of zirconia and titanium was observed by using an analytical transmission electron microscope (Model JEM 2010, JEOL Ltd., Tokyo, Japan) as well as a scanning electron microscope (Model JXA 6400P, JEOL Ltd., Tokyo, Japan). Cross-sectional TEM specimens perpendicular to the interface of zirconia and titanium were prepared by standard procedures of cutting, grinding, polishing, and ion milling. Quantitative composition analyses were carried out based on the principle of Cliffs-Lorimer with an energy-dispersive spectrometer (EDS; Model ISIS 300, Oxford Instrument Inc., London, U.K.) attached to the transmission electron microscope.

The oxygen partial pressure of the argon protective atmosphere in the tungsten mesh furnace was quite low $\left(\sim 10^{-5}\right.$ torr). In addition, the zirconia plate was tightly packed in titanium powders that could scavenge the residual oxygen to further reduce the oxygen partial pressure. In the regions far away from the interface, the oxygen content of titanium was negligible and the zirconia was slightly reduced to $\mathrm{ZrO}_{1.9}$ after firing. Thus, the effect of the residual oxygen content in the furnace on the interfacial reaction was very limited. In other words, the compositional and microstructural variations observed in the present study were mainly caused by the interfacial reactions between titanium and zirconia.

\section{Results and Discussion}

Figure 1(a) is an SEM micrograph of the cross section normal to the interface of $\mathrm{Ti} / 3 \mathrm{Y}-\mathrm{ZrO}_{2}$ after reaction at $1750^{\circ} \mathrm{C}$ for $7 \mathrm{~min}$. Zirconia, at the left of the micrograph, was believed to be oxygen deficient and dissolved some titanium. At the right portion of this micrograph, a featherlike phase existed in the grain boundaries of titanium, being identified as one of the $\mathrm{Ti}-\mathrm{Zr}-\mathrm{O}$ compounds. Figure 1(b) displays a larger magnification of the featherlike phase. There were many pores at both sides of the $\mathrm{Ti} / \mathrm{ZrO}_{2}$. The larger pores in $\mathrm{ZrO}_{2}$ were attributed to the Kirkendall effect, since $\mathrm{Zr}$ diffused to the right more rapidly than Ti diffused toward the left. The smaller pores at the grain boundaries of $\mathrm{Ti}$ were oxygen bubbles formed by the reduction of $\mathrm{ZrO}_{2}$. While liquid titanium could dissolve a significant amount of oxygen, excess oxygen was likely to accumulate as bubbles along the grain boundaries of $\alpha$-Ti.

Figure 2(a) displays the lamellar structure of the featherlike phase. From the selected area diffraction patterns (SADPs)

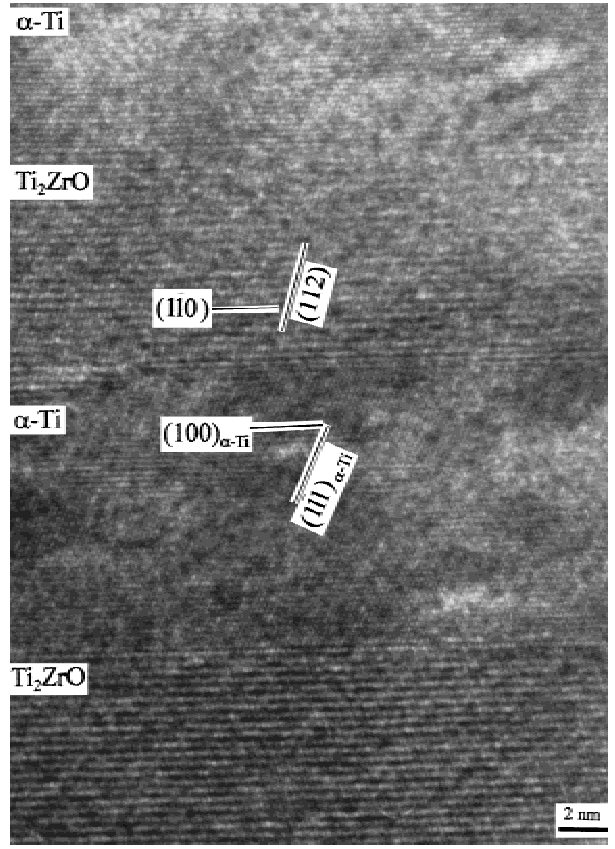

Fig. 3. HRTEM micrograph of the lamellae of $\mathrm{Ti}_{2} \mathrm{ZrO}$ and $\alpha$-Ti.

(Figs. 2(b) and (c)) and the energy dispersive spectrum (EDS) (Fig. 2(d)), the lamellar phase was identified to be orthorhombic $\mathrm{Ti}_{2} \mathrm{ZrO}$ that precipitated in $\alpha$-Ti with an orientation relationship of $\{1 \overline{1} 0\}_{\mathrm{Ti}_{2} \mathrm{ZrO}} / /\{100\}_{\alpha-\mathrm{Ti}}$ and $\langle 11 \overline{1}\rangle_{\mathrm{Ti}_{2} \mathrm{ZrO}} / /\langle 011\rangle_{\alpha-\mathrm{Ti}}$. Figure 3 presents a high-resolution TEM micrograph of alternative layers of $\mathrm{Ti}_{2} \mathrm{ZrO}$ and $\alpha$-Ti. One likely scenario is that the lamellae of $\mathrm{Ti}_{2} \mathrm{ZrO}$ precipitated and grew preferably along the (100) plane of $\alpha$-Ti. $\mathrm{ZrO}_{2}$ is very soluble in Ti, allowing a solid solution of $\alpha-\mathrm{Ti}(\mathrm{Zr}, \mathrm{O})$ to form. ${ }^{16}$ It is likely that $\mathrm{Ti}_{2} \mathrm{ZrO}$ precipitated as $\alpha-\mathrm{Ti}(\mathrm{Zr}, \mathrm{O})$ was cooled down to room temperature. On the transformation of $\alpha-\mathrm{Ti}(\mathrm{Zr}, \mathrm{O}) \rightarrow$ $\mathrm{Ti}_{2} \mathrm{ZrO}$, the crystal structure changed from hexagonal to orthorhombic. The morphology and location of the lamellar $\mathrm{Ti}_{2} \mathrm{ZrO}$ are similar to those reported previously. ${ }^{16}$

Figures 4(a) and (b) show micrographs of $\alpha$-titanium and oxygen-deficient zirconia, respectively, which were formed by the reduction of zirconia by titanium at high temperatures. They were identified to be hexagonal and cubic, respectively, in structure by the inset SADPs. The EDS in Fig. 4(c) indicates that titanium dissolved a small amount of $\mathrm{Zr}$ and $\mathrm{O}$, being designated as $\alpha$-Ti( $\mathrm{Zr}, \mathrm{O})$. Meanwhile, oxygen-deficient zirconia $\left(\mathrm{ZrO}_{1.53}\right)$ dissolved 1.8 at.\% Ti and retained some yttrium (5.83 at.\%) as indicated by Fig. 4(d). These results indicate that zirconia was reduced to oxygen-deficient zirconia by titanium, which was also featured by its dark gray color. ${ }^{2,17,18}$ As mentioned in the previous section, the $\mathrm{O} / \mathrm{Zr}$ ratio was comparatively large $(\sim 1.9)$ in the regions far away from the interface. This implies that the reaction between titanium and zirconia significantly lowered the $\mathrm{O} / \mathrm{Zr}$ ratio $(\sim 1.53)$ of zirconia in the region near the interface.

$\alpha-\mathrm{Zr}$ was found together with $c-\mathrm{ZrO}_{2-x}$ near the interface in the zirconia side. It had a twinned structure with kinks as shown in Fig. 5(a). The corresponding SADP in Fig. 5(b) confirms that the twin plane of $\alpha-\mathrm{Zr}$ was (10) 2 ). This is consistent with the results found in the $\mathrm{Zr}-20 \% \mathrm{Ti}$ alloy by Banerjee and Krishnan. ${ }^{19}$ The phase diagram of $\mathrm{Zr}-\mathrm{O}$ displays a two-phase region of $\alpha-\mathrm{Zr}(\mathrm{O})$ and $c-\mathrm{ZrO}_{2-x}$ in a wide region $(32.5$ at.\% $\mathrm{O}-63.5$ at.\% O) at $1750^{\circ} \mathrm{C}$, and the solubility of $\alpha-\mathrm{Zr}$ in cubic $\mathrm{ZrO}_{2-x}$ decreased with decreasing temperature. ${ }^{20}$ Therefore, the $\alpha-\operatorname{Zr}(\mathrm{O})$ has a tendency to precipitate from the supersaturated solid solution of $\mathrm{ZrO}_{2-x}$ during cooling, and zirconia with a higher $\mathrm{O} / \mathrm{Zr}$ ratio could be obtained by the exclusion of $\mathrm{Zr}$. 
(a)
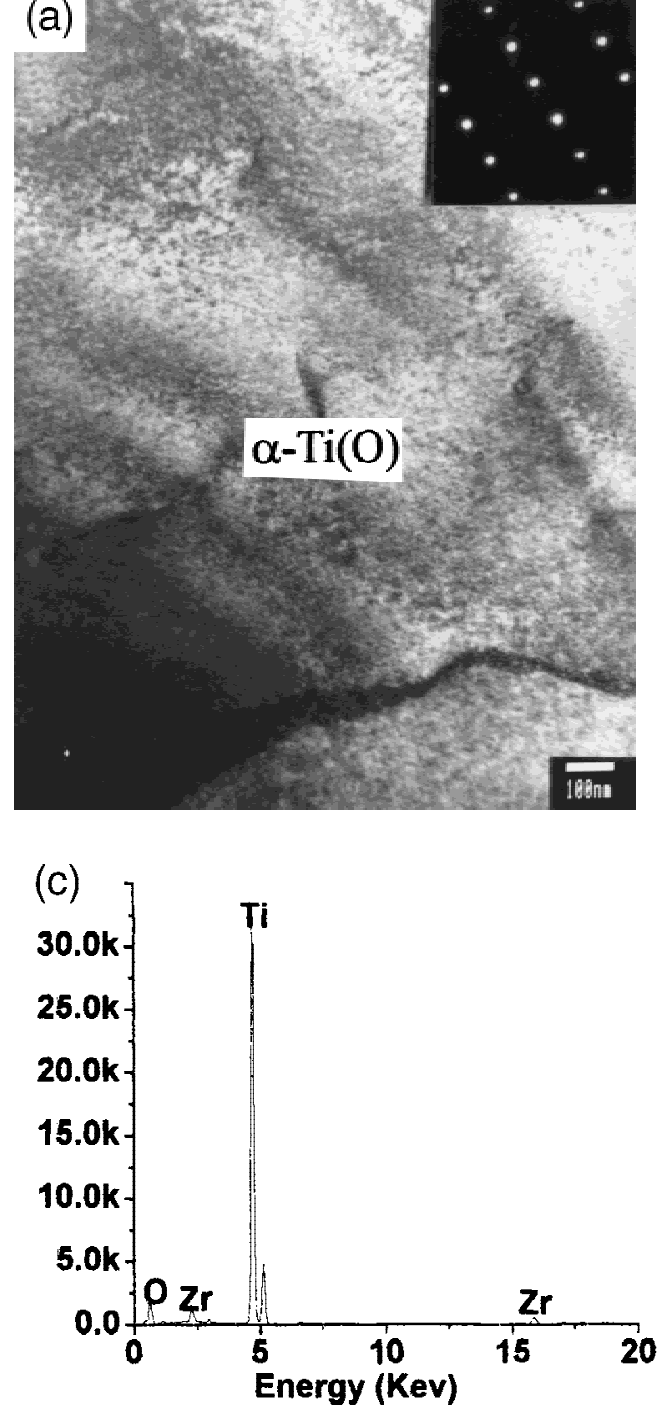
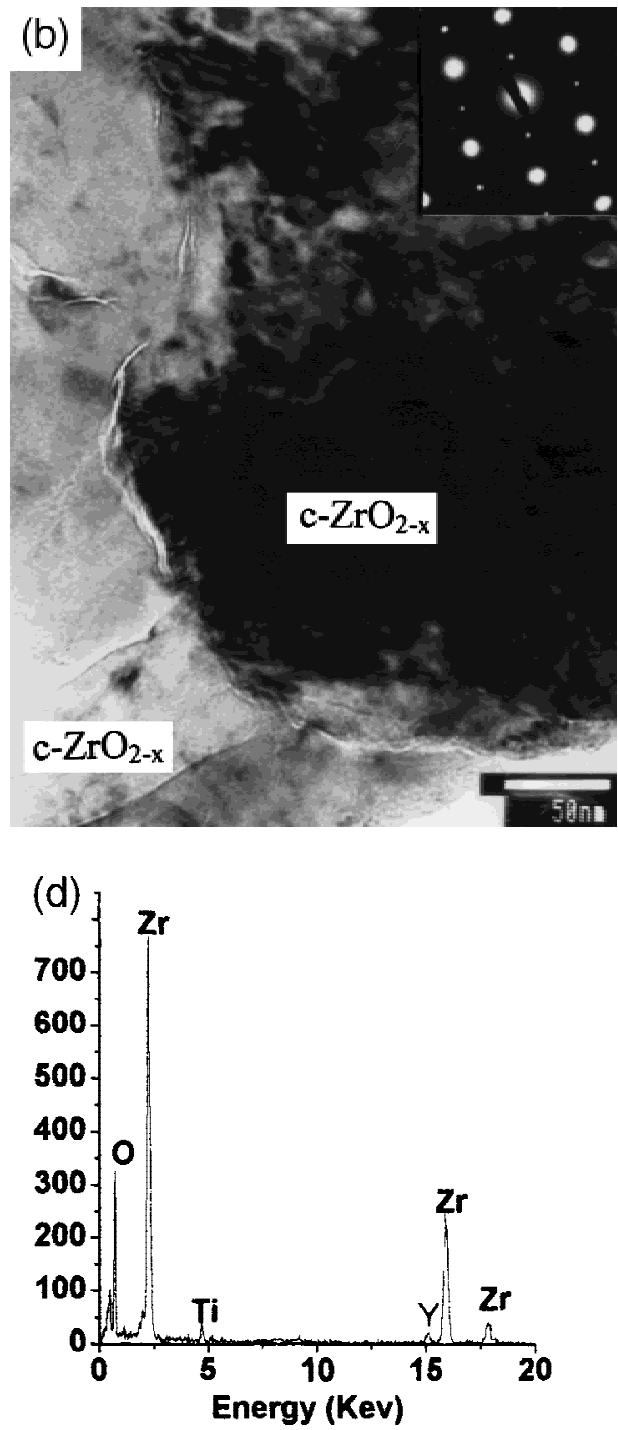

Fig. 4. (a) Bright-field image of $\alpha$-Ti. (b) Bright-field image of $c-\mathrm{ZrO}_{2-x}$. (c) EDS of $\alpha$-Ti. (d) EDS of $c-\mathrm{ZrO}_{2-x}$.

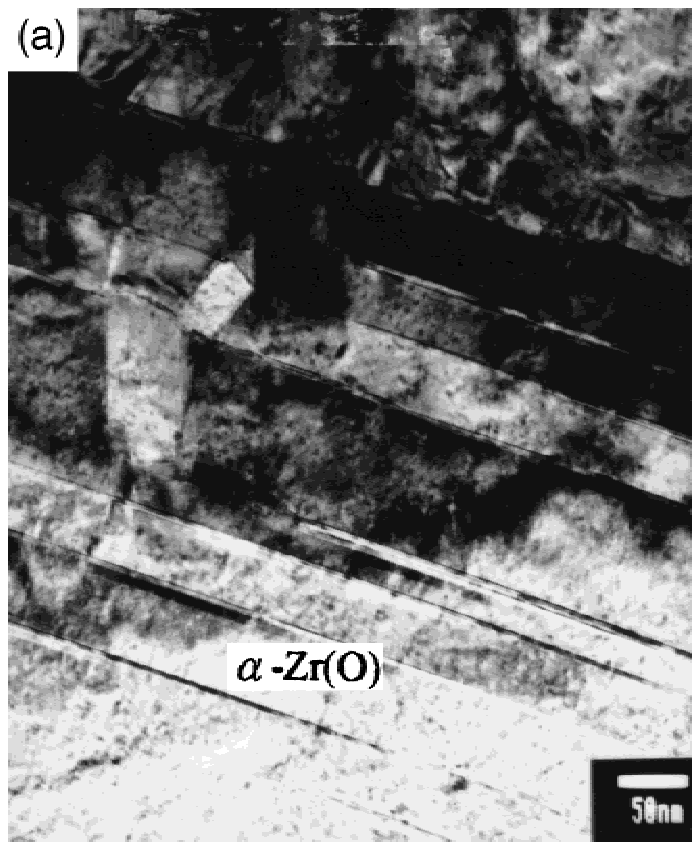

(b)

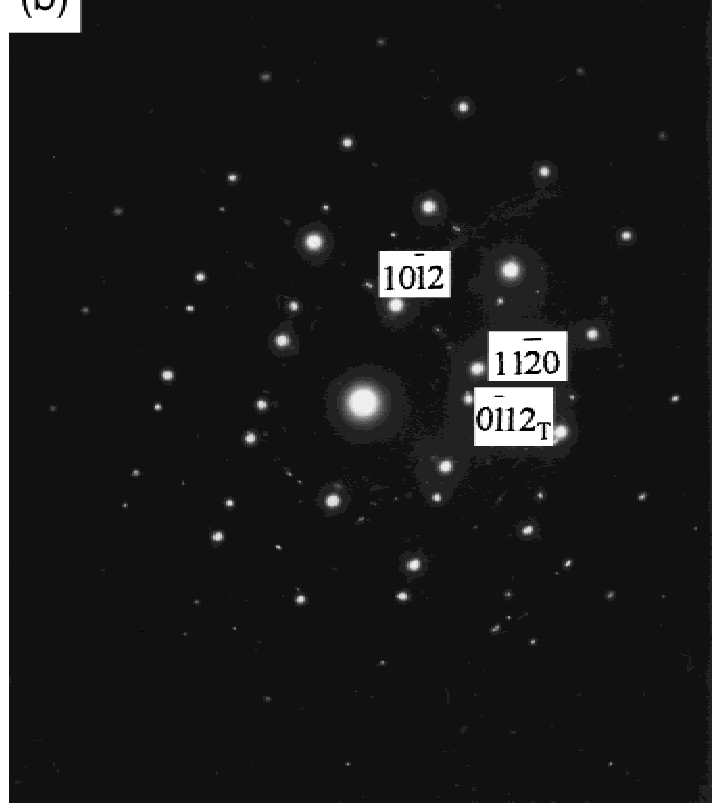

Fig. 5. (a) Bright-field image of microtwinned $\alpha-\operatorname{Zr}(\mathrm{O})$. (b) SADP, $Z=[2 \overline{2} 0 \overline{1}]$. The Miller indices with a subscript $\mathrm{T}$ are for the twins. 

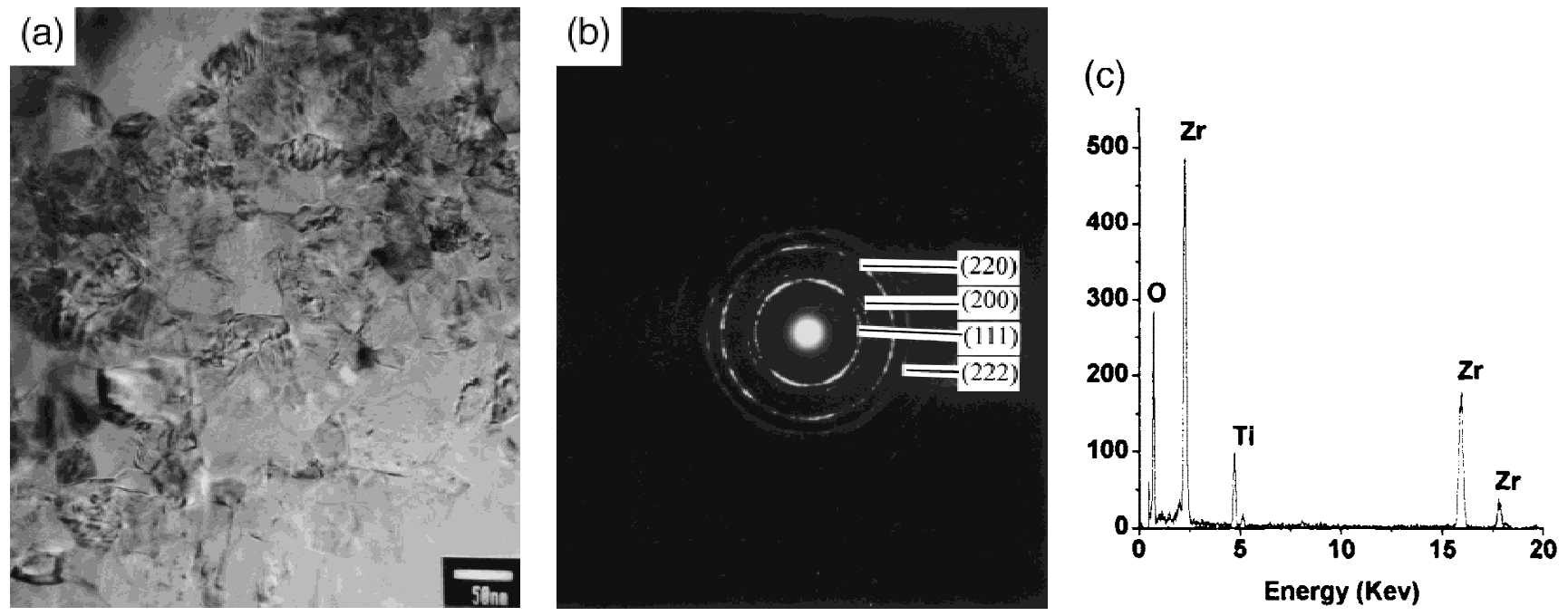

Fig. 6. (a) Bright-field image displaying nanocrystalline $c-\mathrm{ZrO}_{2-x}$. The ring pattern (b) and EDS (c) of these fine $c-\mathrm{ZrO}_{2-x}$.

(a)

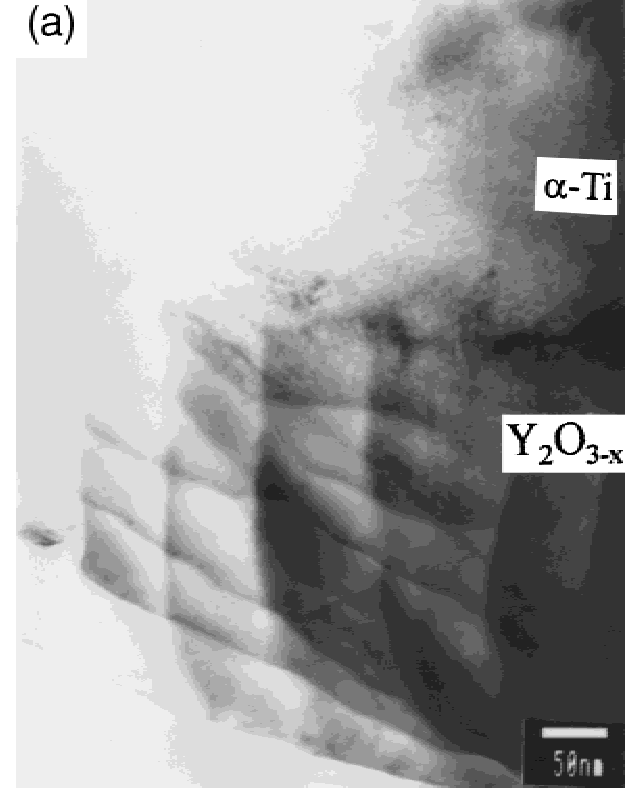

(c)

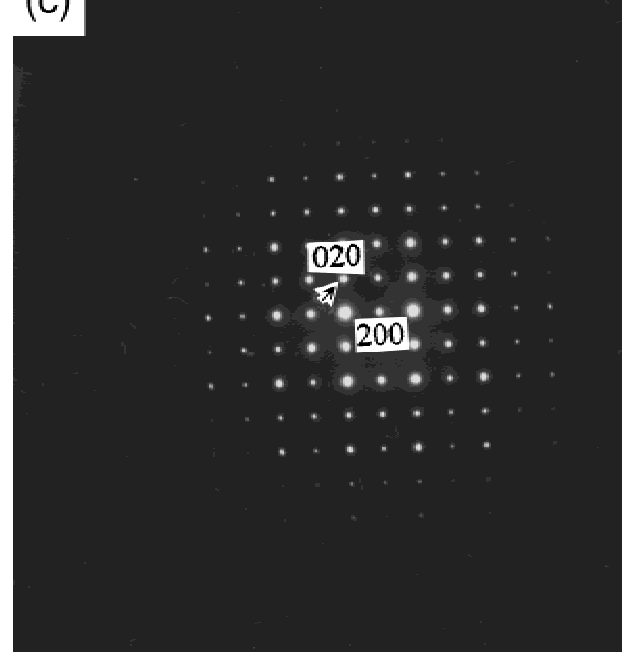

(b)

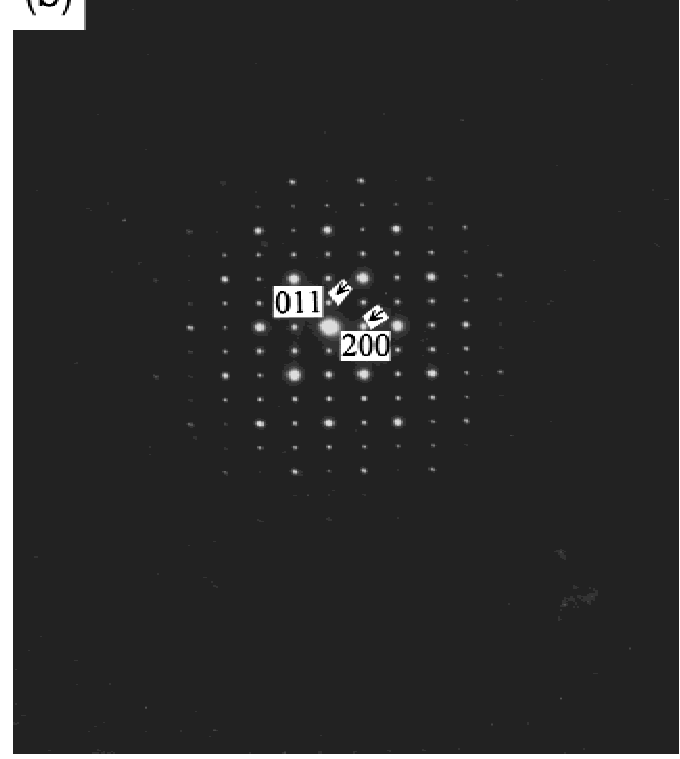

(d)

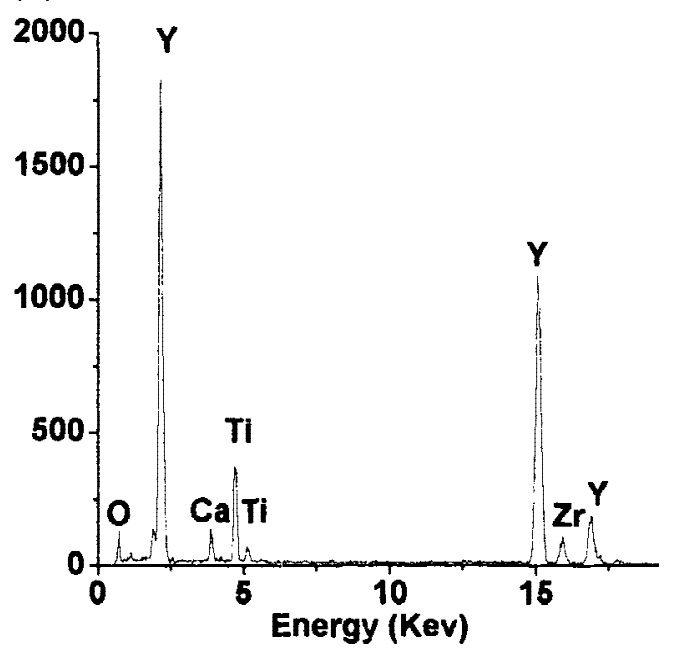

Fig. 7. (a) Bright-field image of $\mathrm{YO}_{0.55}$ adjacent to $\alpha$-Ti. The SADPs of $\mathrm{YO}_{0.55}$ viewed in (b) $Z=[01 \overline{1}]$ and (c) $Z=[001]$. (d) EDS. 

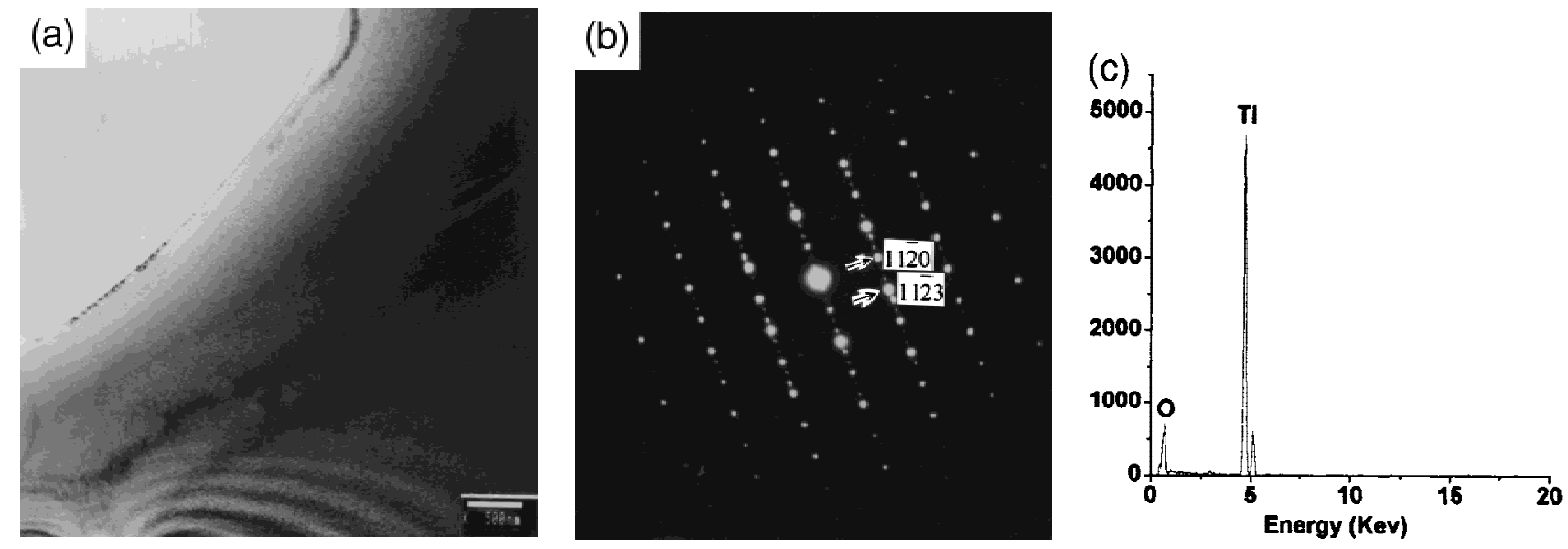

Fig. 8. (a) Bright-field image of $\mathrm{Ti}_{3} \mathrm{O}$. (b) SADP, $Z=[\overline{1} 100]$. (c) EDS.

Figure 6(a) shows a bright-field image of nanocrystalline $\mathrm{ZrO}_{2}$ near the interface. Its SADP is shown in Fig. 6(b), the ring pattern being identified to be that of cubic zirconia. The EDS in Fig. 6(c) shows that the composition of these $\mathrm{ZrO}_{2-x}$ crystallites $(6.95$ at. $\% \mathrm{Ti}, 60.83$ at.\% $\mathrm{O}$, and 32.22 at.\% $\mathrm{Zr}$ ) corresponds to that of oxygen-deficient zirconia $\left(\mathrm{ZrO}_{1.9}\right)$. It is worth noting that this fine crystalline $\mathrm{ZrO}_{2-x}$ phase contains no yttrium.

The lower phase boundary of the solidus of $\mathrm{ZrO}_{2-x}$ phase lies within the composition range $1.64<\mathrm{O} / \mathrm{Zr}<1.70$ from $1815^{\circ}$ to $2065^{\circ} \mathrm{C}$, and 1.925 to 2.0 at $1300^{\circ} \mathrm{C} .{ }^{21,22}$ In the present study, the $\mathrm{O} / \mathrm{Zr}$ ratio of the cubic $\mathrm{ZrO}_{2-x}$ was found to be as low as 1.53. This is not surprising because the equilibrium state was not reached after rapid cooling. While the lowest temperature for cubic oxygen-deficient zirconia is reported to be $1525^{\circ} \mathrm{C},{ }^{20}$ this retained cubic phase was attributed to the presence of $\mathrm{Y}$. On the other hand, the fine $c-\mathrm{ZrO}_{2}$ (Fig. 6(a)) is likely the result of nonequilibrium cooling as well as the size effect.

Figure 7 (a) shows that oxygen-deficient yttria $\left(\mathrm{Y}_{2} \mathrm{O}_{3-x}\right)$ existed in the metal side. The SADPs in Figs. 7(b) and (c) confirm that it is a cubic phase. The EDS in Fig. 7(d) corresponds to oxygen-deficient yttria $\left(\mathrm{YO}_{0.55}\right)$ containing 10.4 at.\% $\mathrm{Ti}$ and 5.9 at.\% Zr. As mentioned above, a significant amount of yttria-stabilized zirconia can be dissolved in $\alpha$-Ti. Since the solubility of $\mathrm{Y}_{2} \mathrm{O}_{3}$ in $\alpha$-Ti was negligible, yttria precipitated during cooling. Like $\mathrm{ZrO}_{2-x}, \mathrm{Y}_{2} \mathrm{O}_{3-x}$ was preferable because of reduction by titanium.

Figures 8(a) and (b) display the bright-field image of $\mathrm{Ti}_{3} \mathrm{O}$ and the corresponding SADP, respectively. The superlattice reflections $(00 \cdot 1),(00 \cdot 2),(11 \cdot 1)$, and $(11 \cdot 2)$ in Fig. 8 (b) indicate that this phase is an ordered structure of $\mathrm{Ti}_{3} \mathrm{O}$. These reflections showed a significant discrepancy with the model proposed by Yamaguchi, ${ }^{23}$ because the superlattice reflections of $(00 \cdot 2)(11 \cdot 1)(11 \cdot 2)$ were the fundamental spots in the model. However, these superlattice reflection spots were consistent with the following conditions proposed by Jostsons and Malin: ${ }^{24}(00 \cdot l)_{\mathrm{Ti}_{3} \mathrm{O}}$ extinction for $l \neq 3 n$, and $(h h \cdot l)_{\mathrm{Ti}_{3} \mathrm{O}}$ extinction for $l \neq 3 n$. The EDS in Fig. 8(c) reveals that the ordered phase contained 75.41 at.\% $\mathrm{Ti}$ and 24.59 at.\% O, approximating the composition of $\mathrm{Ti}_{3} \mathrm{O}$. Thus, the ordered structure of $\mathrm{Ti}_{3} \mathrm{O}$ observed in this study coincided with the model proposed by Jostsons and Malin rather than the one by Yamaguchi. These results revealed that the structure of $\mathrm{Ti}_{3} \mathrm{O}$ was a superstructure of the $\mathrm{Ti}_{2} \mathrm{O}$ unit cell with lattice parameters $a^{\prime}=\sqrt{3 a}$ and $c^{\prime}=3 c$ instead of the parameters $a^{\prime}=\sqrt{3} a$ and $c^{\prime}=2 c$. The Ti-O phase diagram ${ }^{25}$ shows that oxygen has a large solubility in $\alpha$-Ti at high temperatures, while the ordered hexagonal phases $\mathrm{Ti}_{2} \mathrm{O}, \mathrm{Ti}_{3} \mathrm{O}$, and possibly $\mathrm{Ti}_{6} \mathrm{O}$ are formed within an extended range at low temperatures. In this study, the titanium reacted with zirconia and became $\alpha$-Ti(O) as a result of interfacial reactions. However, only $\mathrm{Ti}_{3} \mathrm{O}$ was transformed from $\alpha-\mathrm{Ti}(\mathrm{O})$ during cooling.

\section{Conclusions}

The interfacial reactions between zirconia and titanium were investigated using analytical TEM and SEM. At high temperatures, zirconia could be extensively dissolved into the titanium melt. During cooling, the lamellae of $\mathrm{Ti}_{2} \mathrm{ZrO}$ precipitated in $\alpha$-Ti with an_orientation relationship of $\{1 \overline{1} 0\}_{\mathrm{Ti}_{2} \mathrm{ZrO}} / /\{100\}_{\alpha-\mathrm{Ti}}$ and $\langle 11 \overline{1}\rangle_{\mathrm{Ti}_{2} \mathrm{ZrO}} / /\langle 011\rangle_{\alpha-\mathrm{Ti}}$. In the ceramic side, zirconia was reduced by titanium, resulting in oxygen-deficient oxygen zirconia with $\mathrm{O} / \mathrm{Zr}$ as low as 1.53. A twinned $\alpha-\mathrm{Zr}$ as well as a fine crystalline $\mathrm{ZrO}_{2-x}$ phase $(\mathrm{O} / \mathrm{Zr}$ $\approx 2$ ) was also found near the interface in the ceramic side. Evolution of oxygen entailed the reduction of zirconia. Part of the evolved oxygen was formed as bubbles and the remainder was dissolved in the melt to form $\alpha$-Ti(O) solid solution. An ordered titanium sub-oxide $\left(\mathrm{Ti}_{3} \mathrm{O}\right)$ resulted from the $\alpha$-Ti(O) solid solution. The stabilizer yttria was extracted from yttriapartially-stabilized zirconia and reduced to oxygen-deficient yttria by titanium.

\section{References}

${ }^{1}$ R. L. Saha and K. T. Jacob, "Casting of Titanium and Its Alloys," Def. Sci. J., 36 [2] 121-41 (1986)

${ }^{2}$ R. Ruh, "Reaction of Zirconia and Titanium at Elevated Temperatures," $J$ Am. Ceram. Sco., 46 [7] 301-306 (1963).

${ }^{3}$ M. J. Donachie, Titanium: A Technical Guide; Ch. 11, p. 162. ASM International, Metals Park, OH, 1988.

${ }^{4} \mathrm{G}$. Welsch and W. Bunk, "Deformation Modes of the Alpha-Phase of Ti6A1-4V as a Function of Oxygen Concentration and Aging Temperature," Metall. Trans. A, 13A [5] 889-99 (1982).

${ }^{5}$ K. I. Suzuki, S. Watakabe, and K. Nishikawa, "Stability of Refractory Oxides for Mold Material of Ti-6A1-4V Alloy Precision Casting," J. Jpn. Inst. Met., 60 [8] 734-43 (1996).

${ }^{6}$ A. I. Kahveci and G. E. Welsch, "Effect of Oxygen on the Hardness and Alpha/Beta Phase Ratio of Ti-6A1-4V Alloy," Scr. Metall., 20 [9] 1287-90 (1986).

${ }^{7}$ R. Ruh, N. M. Tallan, and H. A. Lipsitt, "Effect of Metal Additions on the Microstructure of Zirconia," J. Am. Ceram. Soc., 47 [12] 632-35 (1964).

${ }^{8} \mathrm{G}$. Economos and W. D. Kingery, "Metal-Ceramic Interactions: II, MetalOxide Interfacial Reactions at Elevated Temperatures," J. Am. Ceram. Soc., 36 [12] 403-409 (1953)

${ }^{9}$ B. C. Weber, W. M. Thompson, H. O. Bielstein, and M. A. Schwartz, "Ceramic Crucible for Melting Titanium," J. Am. Ceram. Soc., 40 [11] 363-73 (1957)

${ }^{10}$ R. L. Saha, T. K. Nandy, R. D. K. Misra, and K. T. Jacob, "On the Evaluation of Stability of Rare Earth Oxides Face Coats for Investment Casting of Titanium," Metall. Trans., 21B [6] 559-66 (1990).

${ }^{11}$ R. L. Saha, T. K. Nandy, R. D. K. Misra, and K. T. Jacob, "On the Evaluation of the Reactivity of Titanium with Mould Materials during Casting," Bull. Mater. Sci., 12 [5] 481-93 (1989).

${ }^{12}$ S. R. Lyon, S. Inouye, C. A. Alexander, and D. E. Niesz, "The Interaction of Titanium with Refractory Oxides"; pp. 271-84 in Titanium Science and Technology, Vol. 1. Edited by R. I. Burte and H. M. Burte. Plenum Press. New York, 1978.

${ }^{13}$ R. Ruh and H. J. Garrett, "Nonstoichiometry of $\mathrm{ZrO}_{2}$ and Its Relation to Tetragonal-Cubic Inversion in $\mathrm{ZrO}_{2}$," J. Am. Ceram. Soc., 50 [5] 257-61 (1967).

${ }^{14}$ B. C. Weber, H. J. Garrett, F. A. Mauer, and M. A. Schwartz, "Observations on the Stabilization of Zirconia," J. Am. Ceram. Soc., 39 [6] 197-207 (1956). 
${ }^{15}$ C. L. Lin, D. Gan, and P. Shen, "Stabilization of Zirconia Sintered with Titanium," J. Am. Ceram. Soc., 71 [8] 624-29 (1988).

${ }^{16}$ R. F. Domagala, S. R. Lyon, and R. Ruh, "The Pseudobinary Ti-ZrO ${ }_{2}, " J$. Am. Ceram. Soc., 56 [11] 584-87 (1973).

${ }^{17} \mathrm{G}$. M. Ingo, "Origin of Darkening in $8 \mathrm{wt} \%$ Yttria-Zirconia PlasmaSprayed Thermal Barrier Coatings," J. Am. Ceram. Soc., 74 [2] 381-86 (1991).

${ }^{18}$ R. W. Rice, "Comment on Black Color in Partially Stabilized Zirconia," J. Am. Ceram. Soc., 74 [7] 1745-46 (1991).

${ }^{19} \mathrm{~S}$. Banerjee and R. Krishnan, "Martensitic Transformation in $\mathrm{Zr}-\mathrm{Ti}$ Alloys," Metall. Trans., 4 [8] 1811-19 (1973).

${ }^{20}$ H. Baker, ASM Handbook, Vol. 3, Alloy Phase Diagrams; p. 2.326. ASM International, Metals Park, OH, 1992.
${ }^{21}$ R. J. Ackermann, S. P. Garg, and E. G. Rauh, "High-Temperature Phase Diagram for the System Zr-O,” J. Am. Ceram. Soc., 60 [7-8] 341-45 (1977). ${ }^{22}$ R. J. Ackermann, S. P. Garg, and E. G. Rauh, "The Lower Phase Boundary of $\mathrm{ZrO}_{2}$ " J. Am. Ceram. Soc., 61 [5-6] 275-76 (1978).

${ }^{23} \mathrm{~S}$. Yamaguchi, "Interstitial Order-Disorder Transformation in the Ti-O Solid Solution. I. Ordered Arrangement of Oxygen," J. Phys. Soc. Jpn., 27 [1] 155-63 (1969).

${ }^{24}$ A. Jostsons and A. S. Malin, "The Ordered Structure of $\mathrm{Ti}_{3} \mathrm{O}$," Acta Crystallogr., B24 [4] 211-13 (1968).

${ }^{25}$ J. L. Murray and H. A. Wriedt, "The Oxygen-Titanium System”; pp. 21129 in Phase Diagrams of Binary Titanium Alloys. Edited by J. L. Murray. ASM International, Metals Park, OH, 1987. 